\title{
Study of Radionuclides and Radon Exhalation Rate in Soil and Sand Samples from Tiba, Luxor, Governorate
}

\author{
Hani H. Negm¹, Nour K. Ahmed², Abdelbaset Abbady', Maha M. Reda ${ }^{3}$ \\ ${ }^{1}$ Faculty of Science, Assiut University, Assiut, Egypt \\ ${ }^{2}$ Faculty of Science, South Valley University, Qena, Egypt \\ ${ }^{3}$ High Institute of Engineering and Technology at El-Tod, Luxor, Egypt \\ Email: negm_sci@yahoo.com,nkahmed54@yahoo.com,mousa_19@yahoo.com,mahareda2015@yahoo.com
}

How to cite this paper: Negm, H.H., Ahmed, N.K., Abbady, A. and Reda, M.M. (2019) Study of Radionuclides and Radon Exhalation Rate in Soil and Sand Samples from Tiba, Luxor, Governorate. World Journal of Nuclear Science and Technology, 9, 84-95.

https://doi.org/10.4236/wjnst.2019.92006

Received: March 10, 2019

Accepted: April 22, 2019

Published: April 25, 2019

Copyright $\odot 2019$ by author(s) and Scientific Research Publishing Inc. This work is licensed under the Creative Commons Attribution International License (CC BY 4.0).

http://creativecommons.org/licenses/by/4.0/

\begin{abstract}
In this study, the natural radionuclides in soil and sand have been measured by using high purity germanium (HPGe) detector. While, radon exhalation rate has been measured by Alpha GUARD. The data analysis is performed to determine ${ }^{226} \mathrm{Ra},{ }^{232} \mathrm{Th}$, and ${ }^{40} \mathrm{~K}$ activity concentrations in addition to ${ }^{222} \mathrm{Rn}$ exhalation rate. The values of radium equivalent activity $\left(R_{\text {aeq }}\right)$, external hazard index $\left(H_{e x}\right)$, internal hazard index $\left(H_{i n}\right)$, and absorbed dose rate were ranged from 46.46 to $124.16 \mathrm{~Bq} \cdot \mathrm{kg}^{-1}, 0.07$ to $0.33 \mathrm{~Bq} \cdot \mathrm{kg}^{-1}, 0.09$ to $0.42 \mathrm{~Bq} \cdot \mathrm{kg}^{-1}$, and 13.24 to $58.37 \mathrm{nGy} \cdot \mathrm{h}^{-1}$ respectively in all samples. The area and mass exhalation rates were increased from $9.16 \pm 2.83$ to $16.18 \pm 2.83 \mathrm{~Bq} \cdot \mathrm{m}^{-2} \cdot \mathrm{h}^{-1}$ and $1.8 \pm 1.34$ to $11.35 \pm 0.98 \mathrm{~Bq} \cdot \mathrm{kg}^{-1} \cdot \mathrm{h}^{-1}$ respectively.
\end{abstract}

\section{Keywords}

HPGe Detector, Alpha GUARD, Natural Radionuclides, Hazard Index, Radon Gas

\section{Introduction}

In soil and sand, the natural radionuclides consist mainly of ${ }^{232} \mathrm{Th}$ and ${ }^{238} \mathrm{U}$ and isotopes with their daughter products in addition to ${ }^{40} \mathrm{~K}$. The natural radioactivity may vary from one type of soil to another; the sources of radioactivity in soil other than those of natural origin are mainly due to extensive use of fertilizers rich in phosphates for agricultural purposes [1]. The information of the concentrations and distribution of the radionuclides in these materials enable one to assess any possible radiological risks to human health [2] [3], and provide useful 
information in the monitoring of environmental contamination by natural radioactivity. Nationwide surveys have been carried out to determine the radium equivalent activity of building materials in many countries [4] [5] [6]. The reason for current interest is due to the fact that external radiation exposures from naturally occurring radionuclides materials (NORM) contribute, on average, of about $10 \%$ of the average annual dose to the human body from all radiation sources. It has been observed that naturally occurring radionuclides are present in soil [7] [8] [9] and sand which constitute a lived-in radioactive environment. In this study, we used The HPGe detector N-type for determining the activity levels of ${ }^{226} \mathrm{Ra},{ }^{232} \mathrm{Th}$ and ${ }^{40} \mathrm{~K}$ in soil and sand samples collected from Tiba area. ALPHA GUARD has been used for evaluating radon exhalation rate. It is well known that radon exhalation of soil samples is higher than sand samples because of the presence of relatively high uranium content in its natural formation [10]. The formatter will need to create these components, incorporating the applicable criteria that follow.

\section{Materials and Methods}

\subsection{Sampling and Samples Preparation}

In this study, 36 samples have been collected from Tiba city Luxor governorate, as presented in Figure 1, for more detailed descriptions. The soil sampling sites were randomly selected for the two types of samples (soil and sand) and samples were collected by a core method, in which cores of $10 \mathrm{~cm}$ diameter and $25 \mathrm{~cm}$ in depth were used to take samples (ASTM, 1986, 1983) [11]. Samples with large grain size were crushed to small pieces using mechanical crusher. Afterwards, the samples were ground to a fine grain size powder. Every powdered sample was mixed using electric shaker to obtain a homogeneous powdered sample. The reason of choosing this region because it is a new reclaimed area and there are no enough researches in it. The samples were divided to, 15 samples of soil and

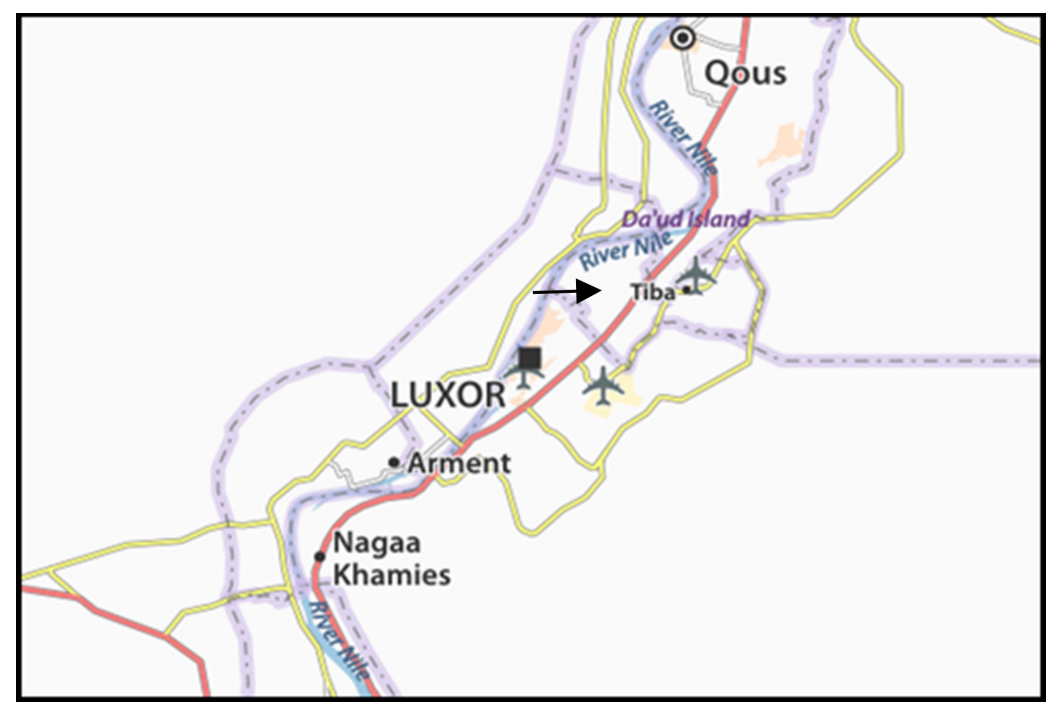

Figure 1. Sampling location (Tiba, Luxor). 
21 samples of sand. Some processes have been done on the samples before measuring the activity concentration for them, like the following: First, the samples dried in an oven at $105^{\circ} \mathrm{C}$, to get rid of moisture and water inside samples. Second, the samples sieved through 200 mesh, to optimize the grain size of the heavy mineral [12]. Third, each sample has been placed in a plastic container, which was sealed to avoid the escape of ${ }^{222} \mathrm{Rn}$ and ${ }^{220} \mathrm{Rn}$ from the samples. Moreover, the samples were left for one month at least to achieve equilibrium between ${ }^{232} \mathrm{Th},{ }^{226} \mathrm{Ra}$, and their daughter products before radiometric analysis [13].

\subsection{Measuring Systems}

\section{1) Measurement activity concentration}

Gamma-ray spectrometry is a commonly used technique for direct determination of the radionuclides in crustal and extra-terrestrial materials. The radioactive analysis in environmental samples often encounters with difficulty in measuring low levels of radioactivity. However, gamma spectrometry is a useful tool in the analysis of natural radionuclides at environmental concentrations. It is a relative method of assay and has the merit of being simple and essentially non-destructive technique. The method is based on the fact that the decay of the radioelements is accompanied by the emission of high energy gamma-rays in order of $\mathrm{Kev}$ to few-MeV. The applied low-level gamma-ray spectrometer is based on the high purity germanium (HPGe) detector with its electronic instrumentation. The detector is the coaxial closed end, closed facing window geometry with vertical dipstick cryostat with carbon composite window.

The detector-crystal has been shielded in a chamber of three layers starting with copper (30 mm thick), lead (100 mm thick) and finally cadmium ( $3 \mathrm{~mm}$ thick). This shield serves in reducing the background-radiation for the measuring sample to less than 1\%. Figure 2 shows the block diagram of a low-level gamma-rays spectrometer, which consists of; the preamplifier, the main amplifier, multichannel analyzer, and the scalar or PC. Each sample was placed in face to face geometry over the detector for about 8 hours or more for the natural radionuclide's $\left({ }^{226} \mathrm{Ra},{ }^{232} \mathrm{Th}\right.$ and $\left.{ }^{40} \mathrm{~K}\right)$ in soil and sand samples. Signals produced by the gamma-ray detector are amplified, stored and displayed by the multichannel analyzer as well as the energy spectra, i.e. the number of counts per unit time per energy interval.

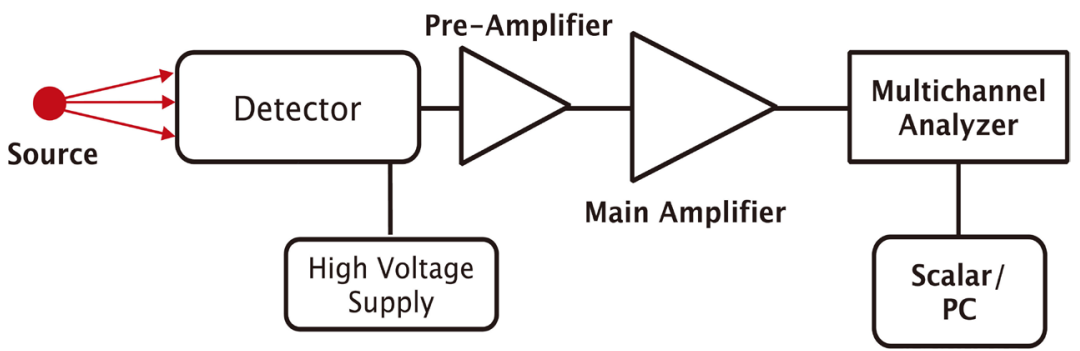

Figure 2. Block diagram of a gamma-ray spectrometer. 
The activity concentrations have been calculated from the intensity of each line considering the size and mass of the sample, the branching ratio for the gamma-decay, and the efficiency of the detector. The branching ratio is the statistical chance that a gamma-ray is emitted per decaying nucleus. The efficiency of the detector represents the probability that the emitted gamma-ray contributes to the line in the spectrum. Activity concentrations calculated from the intensity of several gamma-rays emitted by a nucleus are grouped together to produce a weighted average activity per nuclide. For activity concentrations of nuclides in the same decay series, the activity concentrations are grouped in a similar way.

The analysis of ${ }^{226} \mathrm{Ra}$ and ${ }^{232} \mathrm{Th}$ is based on the gamma-lines of the decay products in equilibrium with their parent nuclides. The specific activity of ${ }^{226} \mathrm{Ra}$ of the samples has been determined through its daughters $\left({ }^{214} \mathrm{~Pb}\right.$ and $\left.{ }^{214} \mathrm{Bi}\right)$ via the intensity of the $295.2 \mathrm{keV}, 351.9 \mathrm{keV}$ for ${ }^{214} \mathrm{~Pb}$ gamma-lines, and $609.3 \mathrm{keV}$, $1120.3 \mathrm{keV}, 1764.5 \mathrm{keV}$ for ${ }^{214} \mathrm{Bi}$ gamma-lines. The specific activity of ${ }^{232} \mathrm{Th}$ of the samples has been determined from its daughters $\left({ }^{228} \mathrm{Ac},{ }^{212} \mathrm{~Pb}\right.$, and $\left.{ }^{208} \mathrm{Tl}\right)$ via the intensity of $209.3 \mathrm{keV}, 338.3 \mathrm{keV}, 911.2 \mathrm{keV}, 969.0 \mathrm{keV}$ gamma-lines for ${ }^{228} \mathrm{Ac}$, $238.6 \mathrm{keV}$ gamma line of ${ }^{212} \mathrm{~Pb}$, and $583.2 \mathrm{keV}, 2614.6 \mathrm{keV}$ gamma-lines of ${ }^{208} \mathrm{Tl}$, while the specific activity of ${ }^{40} \mathrm{~K}$ has been determined from the emission of $1460.7 \mathrm{keV}$ gamma-line.

Before using the gamma-ray spectrometer for measurements, the following considerations have been made: energy calibration, detection efficiency calibration, and background measurements.

The specific activity concentration $A\left(E_{i}\right)$ with $\mathrm{Bq} \cdot \mathrm{kg}^{-1}$, of a nuclide and for a gamma-line $(i)$ with energy $E$, is given by:

$$
A\left(E_{i}\right)=\frac{N\left(E_{i}\right) / T-n\left(E_{i}\right) / t}{\varepsilon\left(E_{i}\right) \cdot P\left(E_{i}\right) \cdot M}
$$

where, $N\left(E_{i}\right)$ is the counts in a given peak $(i)$ area, $T$ is the sample counting lifetime, $n\left(E_{i}\right)$ is the number of counts in background peak $(i), t$ is the background counting time, $P\left(E_{i}\right)$ is the number of gammas per disintegration of this nuclide (emission probability), $M$ is the mass in $\mathrm{kg}$ of the measured sample, $\varepsilon\left(E_{i}\right)$ is the detection efficiency of the measured gamma-line energy.

If there is more than one peak in the energy analysis range for a nuclide, then an attempt to average the peak activities is made by using the weighted average nuclide activity. Moreover, the concentrations of the radiological hazard indices in the collected samples have been estimated, based on the measured gamma-ray photo-peaks, that emitted from the specific radionuclides in the ${ }^{232} \mathrm{Th}$ and ${ }^{226} \mathrm{Ra}$ decay series as well in ${ }^{40} \mathrm{~K}$. The calculations depend on the establishment of secular-equilibrium for each sample, due to the much smaller lifetime of daughter radionuclides in the decay series of ${ }^{232} \mathrm{Th}$ and ${ }^{226} \mathrm{Ra}$. More specifically, the ${ }^{232} \mathrm{Th}$ concentration was determined from the average activity concentrations of ${ }^{212} \mathrm{~Pb}$, ${ }^{208} \mathrm{Tl}$, and ${ }^{228} \mathrm{Ac}$ in the samples, and that of ${ }^{226} \mathrm{Ra}$ was determined from the average activity concentrations of the ${ }^{214} \mathrm{~Pb}$ and ${ }^{214} \mathrm{Bi}$ decay products. Therefore, an accu- 
rate measurement of ${ }^{232} \mathrm{Th}$ and ${ }^{226} \mathrm{Ra}$ radiological activity concentrations has been made, whereas a true measurement of ${ }^{40} \mathrm{~K}$ concentration was achieved.

\section{2) Measurement of the radon exhalation rate}

To determine the ${ }^{222} \mathrm{Rn}$ exhalation activity concentration in soil and sand samples, the ionization chamber Alpha GUARD PQ2000PRO along with the additional special equipment [14] has been used. The background of the detection system, without a sample, is measured for a few minutes before achieving any measuring. About $200 \mathrm{~g}$ of each sample was put into the degassing vessel. The Alpha-pump was switched on with the flow rate $1.0 \mathrm{~min}$ and $10.0 \mathrm{~min}$ flow, thus the ${ }^{222} \mathrm{Rn}$ activity concentration will be recorded every $10 \mathrm{~min}$. At equilibrium state, the buildup activity of exhaled radon inside the emanation container is as follows:

$$
A=A_{0}\left(1-\mathrm{e}^{-\lambda t}\right)
$$

where $A_{0}$ is the total value of the activity concentration in $\mathrm{Bq} / \mathrm{m}^{3}$ and $\lambda$ is the decay constant of the radon nuclide. The radon exhalation rate of the concerned sample per unit area, $E_{S}$, which known as the radon flux that released via the surface of the material, can be calculated using the following formula [15] [16]:

$$
E_{S}=A_{0} \frac{V}{S} \lambda
$$

where $V$ is the effective volume of the emanation container $\left(2400 \times 10^{-6} \mathrm{~m}^{3}\right)$ and $S$ is the total surface area of the sample $\left(0.01130 \mathrm{~m}^{2}\right)$, which equals the cross-sectional area of the emanation container. By analogy of Equation (3), the radon exhalation rate per unit mass of the concerned sample $E_{M}$ is also calculated using the following formula:

$$
E_{M}=A_{0} \frac{V}{M} \lambda
$$

where $M$ is the sample mass.

\section{Results and Discussions}

\subsection{Natural Activity Concentration}

The activity concentrations of ${ }^{226} \mathrm{Ra}$ and ${ }^{232} \mathrm{Th}$ series, and ${ }^{40} \mathrm{~K}$ acquired from sand samples are ranged from $18.34 \pm 4.24 \mathrm{~Bq} \cdot \mathrm{kg}^{-1}, 14.06 \pm 3.66 \mathrm{~Bq} \cdot \mathrm{kg}^{-1}, 210.99 \pm$ $14.467 \mathrm{~Bq} \cdot \mathrm{kg}^{-1}$, respectively, and for soil samples vary from $15.916 \pm 4.769$ to $34.3073 \pm 5.85 \mathrm{~Bq} \cdot \mathrm{kg}^{-1}, 12.9314 \pm 3.59$ to $40.244 \pm 6.34 \mathrm{~Bq} \cdot \mathrm{kg}^{-1}$ and $135.36 \pm$ 11.63 to $528.144 \pm 22.98 \mathrm{~Bq} \cdot \mathrm{kg}^{-1}$, respectively. The measured activities values have been found within the acceptable range of radioactive concentrations reported by UNSCEAR [17]. A summary of measurements for the activity concentration in Bq. $\mathrm{kg}^{-1}$ of the natural radioactivity due to ${ }^{226} \mathrm{Ra},{ }^{232} \mathrm{Th}$, and ${ }^{40} \mathrm{k}$ of different samples is presented in Table 1 . The distribution of ${ }^{226} \mathrm{Ra},{ }^{232} \mathrm{Th}$, and ${ }^{40} \mathrm{k}$ activity concentrations in all samples are given in Figure 3 \& Figure 4.

\subsection{Radiation Hazard Indices}

Radium equivalent activity $\left(R_{\text {aeq }}\right)$, Internal hazard index $\left(H_{i n}\right)$, External hazard 

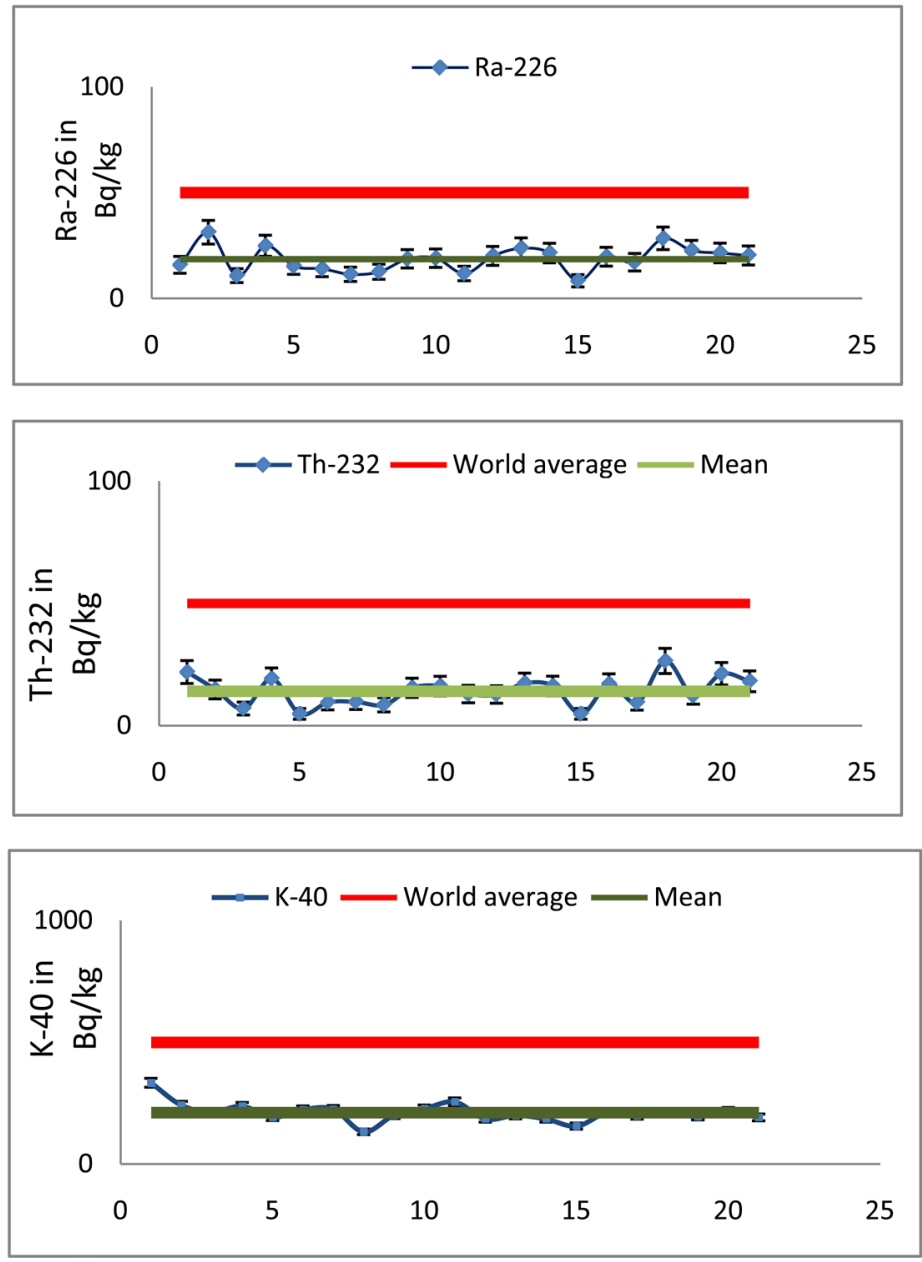

Figure 3. Distribution activity concentration $\left(\mathrm{Bq} \cdot \mathrm{Kg}^{-1}\right)$ of ${ }^{226} \mathrm{Ra},{ }^{232} \mathrm{Th}$ and ${ }^{40} \mathrm{~K}$ for Tiba sand samples.

index $\left(H_{e x}\right)$ and Gamma activity concentration index $\left(I_{\gamma r}\right)$, can be estimated by following equations respectively [18] [19] [20] [21]:

$$
\begin{gathered}
R a_{e q}=A_{R a}+\frac{10}{7} A_{T h}+\frac{10}{130} A_{K} \\
H_{e x}=\frac{1}{370} A_{R a}+\frac{1}{259} A_{T h}+\frac{1}{4810} A_{K} \\
H_{i n}=\frac{1}{185} A_{R a}+\frac{1}{259} A_{T h}+\frac{1}{4810} A_{K} \\
I_{\gamma r}=\frac{1}{150} A_{R a}+\frac{1}{100} A_{T h}+\frac{1}{1500} A_{K}
\end{gathered}
$$

\subsection{Absorbed Dose Rate}

The absorbed dose rate of gamma-ray, $D$, in $\mathrm{nGy} \cdot \mathrm{h}^{-1}$ in the outdoor air at a height $1.0 \mathrm{~m}$ above the ground level can be calculated using the activity concentrations of ${ }^{226} \mathrm{Ra}$ and ${ }^{232} \mathrm{Th}$ series as well ${ }^{40} \mathrm{~K}$ isotope that measured in $\mathrm{Bq} \cdot \mathrm{kg}^{-1}$ as the following equation of UNSCEAR-2000 [17]: 

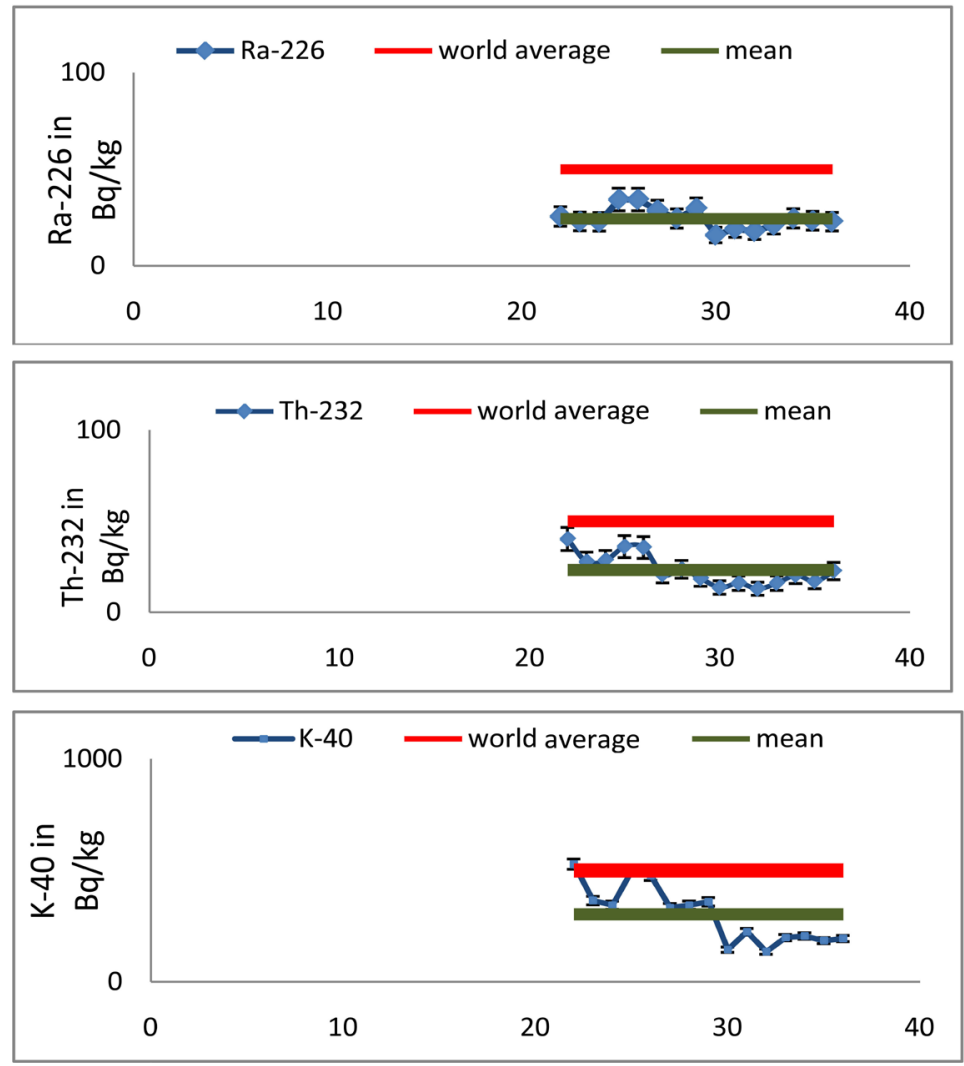

Figure 4. Distribution activity concentration $(\mathrm{Bq} / \mathrm{Kg})$ of ${ }^{226} \mathrm{Ra},{ }^{232} \mathrm{Th}$ and ${ }^{40} \mathrm{~K}$ for Tiba soil samples.

$$
D(\mathrm{nGy} / \mathrm{h})=0.462 A_{R a}+0.604 A_{T h}+0.0416 A_{K}
$$

The calculated absorbed doses in air for soil samples are ranged from 21.58 to $58.37 \mathrm{nGy} \cdot \mathrm{h}^{-1}$ with an average value $37.98 \mathrm{nGy} \cdot \mathrm{h}^{-1}$, while it for sand samples are ranged from 13.24 to $37.84 \mathrm{nGy} \cdot \mathrm{h}^{-1}$ with an average value of $25.85 \mathrm{nGy} \cdot \mathrm{h}^{-1}$. However, according to UNSCEAR-2000 [17], the dose rate in outdoor air from terrestrial gamma-rays in normal circumstances is about $57 \mathrm{nGy} \cdot \mathrm{h}^{-1}$. Consequently, the evaluated doses obtained in this study for all samples are lower than the worldwide average value of $57 \mathrm{nGy} \cdot \mathrm{h}^{-1}$, which attributed to the low of activity concentrations of ${ }^{226} \mathrm{Ra}$ and ${ }^{232} \mathrm{Th}$ series, as well ${ }^{40} \mathrm{~K}$ isotope.

While the results of $R_{a e q}, I_{\gamma r}, H_{i n}, H_{e x}$ and $D$ are given in Table 1.

\subsection{Calculation Radium Content and Exhalation Rates in Soil and Sand Samples Collected from Tiba Region}

Table 2 shows the average values for radium content in $\mathrm{Bq} \cdot \mathrm{kg}^{-1}$, mass exhalation rate in $\mathrm{Bq} \cdot \mathrm{kg}^{-1} \cdot \mathrm{h}^{-1}$, and area exhalation rate in $\mathrm{Bq} \cdot \mathrm{m}^{-2} \cdot \mathrm{h}^{-1}$, for soil and sand samples collected from Tiba region. Figure 5 shows the average value for Radium content (a), mass exhalation rate (b), and area exhalation rate(c), for soil and sand samples. As results of the evaluation of these parameters, the average values for radium content, mass exhalation rate and area exhalation rate for soil samples are higher than of the corresponding values of the sand samples. 
Table 1. Average radionuclide concentrations, radium equivalent activity, external hazard index, internal hazard index, representative level index and absorbed dose rate in different samples from Tiba, Luxor governorate.

\begin{tabular}{|c|c|c|c|c|c|c|c|c|c|}
\hline \multirow{2}{*}{$\begin{array}{c}\text { Sample } \\
\text { No. }\end{array}$} & \multirow{2}{*}{$\begin{array}{l}\text { Type of } \\
\text { sample }\end{array}$} & \multicolumn{3}{|c|}{ Activity concentration $(\mathrm{Bq} / \mathrm{Kg})$} & \multirow{2}{*}{$R_{\text {aeq }}$} & \multirow{2}{*}{$H_{e x}$} & \multirow{2}{*}{$H_{\text {in }}$} & \multirow{2}{*}{$I$} & \multirow{2}{*}{$\begin{array}{l}\text { Absorbed } \\
\text { dose rate }\end{array}$} \\
\hline & & ${ }^{226} \mathrm{Ra}$ & ${ }^{232} \mathrm{Th}$ & ${ }^{40} \mathrm{~K}$ & & & & & \\
\hline 22 & Soil & $25.50 \pm 5$ & $40.24 \pm 6.3$ & $528.1 \pm 22.9$ & 123.71 & 0.33 & 0.4 & 0.92 & 58.11 \\
\hline 23 & & $22.95 \pm 4.7$ & $27.74 \pm 5.2$ & $364.7 \pm 19.1$ & 90.77 & 0.24 & 0.3 & 0.67 & 42.59 \\
\hline 24 & & $22.74 \pm 4.7$ & $28.57 \pm 5.3$ & $343.7 \pm 18.5$ & 90.07 & 0.24 & 0.3 & 0.66 & 42.1 \\
\hline 25 & & $34.30 \pm 5.8$ & $36.05 \pm 6$ & $497.4 \pm 22.3$ & 124.1 & 0.33 & 0.42 & 0.92 & 58.37 \\
\hline 26 & & $34.29 \pm 5.8$ & $35.57 \pm 5.9$ & $476.6 \pm 21.8$ & 121.8 & 0.32 & 0.42 & 0.9 & 57.2 \\
\hline 27 & & $28.54 \pm 5.3$ & $20.70 \pm 4.5$ & $333.1 \pm 18.3$ & 83.54 & 0.22 & 0.3 & 0.61 & 39.58 \\
\hline 28 & & $24.41 \pm 4.9$ & $23.59 \pm 4.8$ & $344.2 \pm 18.6$ & 84.66 & 0.22 & 0.29 & 0.62 & 39.88 \\
\hline 29 & & $29.66 \pm 5.4$ & $18.60 \pm 4.3$ & $358.8 \pm 18.9$ & 83.9 & 0.22 & 0.3 & 0.62 & 39.9 \\
\hline 30 & & $15.91 \pm 3.9$ & $13.59 \pm 3.6$ & $144.30 \pm 12$ & 46.46 & 0.12 & 0.16 & 0.33 & 21.58 \\
\hline 31 & & $19.10 \pm 4.3$ & $16.01 \pm 4$ & $224.8 \pm 14.9$ & 59.3 & 0.16 & 0.21 & 0.43 & 27.86 \\
\hline 32 & & $17.87 \pm 4.2$ & $12.93 \pm 3.5$ & $135.3 \pm 11.6$ & 46.79 & 0.12 & 0.17 & 0.33 & 21.71 \\
\hline 33 & & $21.04 \pm 4.5$ & $16.01 \pm 4$ & $198.2 \pm 14.1$ & 59.21 & 0.15 & 0.21 & 0.43 & 27.66 \\
\hline 34 & & $24.52 \pm 4.9$ & $20.30 \pm 4.5$ & $205.4 \pm 14.3$ & 69.37 & 0.18 & 0.25 & 0.5 & 32.15 \\
\hline 35 & & $23.31 \pm 4.8$ & $17.03 \pm 4.1$ & $185.0 \pm 13.6$ & 61.93 & 0.16 & 0.23 & 0.44 & 28.78 \\
\hline 36 & & $22.83 \pm 4.7$ & $22.60 \pm 4.7$ & $194.2 \pm 13.9$ & 70.11 & 0.18 & 0.25 & 0.5 & 32.3 \\
\hline Max & & $34.30 \pm 5.8$ & $40.24 \pm 6.3$ & $528.1 \pm 22.9$ & 124.16 & 0.33 & 0.42 & 0.92 & 58.37 \\
\hline Min & & $15.91 \pm 4.7$ & $12.93 \pm 3.5$ & $135.3 \pm 11.6$ & 46.46 & 0.12 & 0.16 & 0.33 & 21.58 \\
\hline Aver & & $24.46 \pm 5.2$ & $23.30 \pm 4.7$ & $302.29 \pm 17$ & 81.07 & 0.21 & 0.28 & 0.59 & 37.98 \\
\hline 1 & Sand & $15.88 \pm 3.9$ & $21.9 \pm 4.6$ & $333.5 \pm 18.2$ & 56.07 & 0.19 & 0.23 & 0.54 & 34.47 \\
\hline 2 & & $31.28 \pm 5.5$ & $14.78 \pm 3.8$ & $241.7 \pm 15.5$ & 55.57 & 0.19 & 0.27 & 0.51 & 33.46 \\
\hline 3 & & $10.78 \pm 3.2$ & $6.97 \pm 2.6$ & $213.9 \pm 14.6$ & 85.14 & 0.1 & 0.12 & 0.28 & 18.11 \\
\hline 4 & & $24.9 \pm 4.9$ & $19.2 \pm 4.3$ & $237.2 \pm 15.4$ & 53.17 & 0.19 & 0.25 & 0.51 & 32.99 \\
\hline 5 & & $15.3 \pm 3.9$ & $4.78 \pm 2.1$ & $192.3 \pm 13.8$ & 91.52 & 0.09 & 0.14 & 0.27 & 17.97 \\
\hline 6 & & $14.01 \pm 3.7$ & $9.5 \pm 3.1$ & $223.4 \pm 14.9$ & 73.62 & 0.12 & 0.15 & 0.33 & 21.52 \\
\hline 7 & & $11.4 \pm 3.3$ & $9.7 \pm 3.1$ & $225.0 \pm 15.1$ & 76.04 & 0.11 & 0.14 & 0.32 & 20.51 \\
\hline 8 & & $12.6 \pm 3.5$ & $8.5 \pm 2.9$ & $132.2 \pm 11.5$ & 77.88 & 0.09 & 0.12 & 0.25 & 16.47 \\
\hline 9 & & $18.72 \pm 4.3$ & $15.45 \pm 3.9$ & $200.8 \pm 14.1$ & 60.03 & 0.15 & 0.2 & 0.41 & 26.35 \\
\hline 10 & & $19.01 \pm 4.3$ & $16.16 \pm 4$ & $226.9 \pm 15.1$ & 59.01 & 0.16 & 0.21 & 0.43 & 28 \\
\hline 11 & & $11.8 \pm 3.4$ & $12.9 \pm 3.5$ & $255.3 \pm 15.9$ & 69.4 & 0.13 & 0.16 & 0.37 & 23.89 \\
\hline 12 & & $20.11 \pm 4.4$ & $12.72 \pm 3.5$ & $185.4 \pm 13.6$ & 62.96 & 0.14 & 0.19 & 0.38 & 24.7 \\
\hline 13 & & $23.75 \pm 4.8$ & $17.31 \pm 4.1$ & $199.5 \pm 14.4$ & 55.43 & 0.17 & 0.23 & 0.46 & 29.74 \\
\hline 14 & & $21.45 \pm 4.6$ & $16.2 \pm 4$ & $185.4 \pm 13.6$ & 57.68 & 0.15 & 0.21 & 0.42 & 27.42 \\
\hline 15 & & $8.34 \pm 2.8$ & $4.8 \pm 2.1$ & $155.6 \pm 12.5$ & 100.51 & 0.07 & 0.09 & 0.2 & 13.24 \\
\hline
\end{tabular}




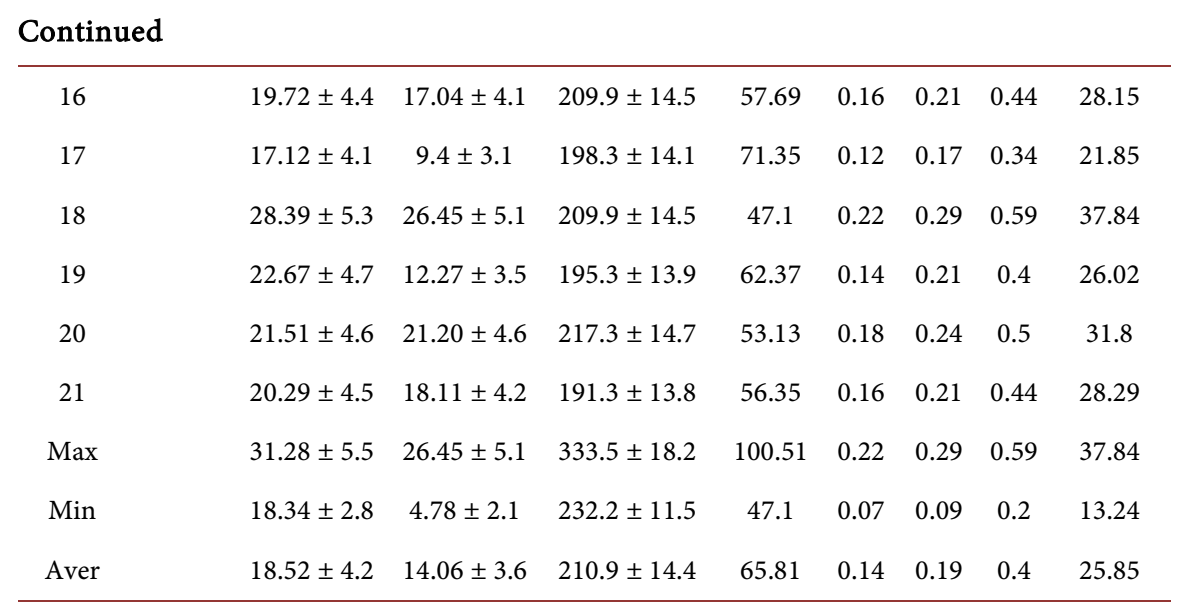

Table 2. The average values for radium content $\left(\mathrm{Bq} \cdot \mathrm{kg}^{-1}\right)$, mass exhalation rate $\left(\mathrm{Bq} \cdot \mathrm{kg}^{-1} \cdot \mathrm{h}^{-1}\right)$ and area exhalation rate $\left(\mathrm{Bq} \cdot \mathrm{m}^{-2} \cdot \mathrm{h}^{-1}\right)$ for soil and sand samples collected from Tiba region.

\begin{tabular}{cccc}
\hline \multirow{2}{*}{ Type of samples } & Radium content $\left(\mathrm{Bq} \cdot \mathrm{kg}^{-1}\right)$ & \multicolumn{2}{c}{ Radon exhalation rate } \\
\cline { 3 - 4 } & $240.25 \pm 15.46$ & Mass $\left(\mathrm{Bq} \cdot \mathrm{Kg}^{-1} \cdot \mathrm{h}^{-1}\right)$ & Surface area $\left(\mathrm{Bq} \cdot \mathrm{m}^{2} \cdot \mathrm{h}^{-1}\right)$ \\
\hline Soil & $152.39 \pm 11.35$ & $1.816 \pm 1.34$ & $16.18 \pm 4.012$ \\
Sand & & $1.1 \pm 0.98$ & $9.16 \pm 2.83$ \\
\hline
\end{tabular}

\section{Conclusion}

High purity germanium was exploited to determine activity concentration for naturally occurring ${ }^{226} \mathrm{Ra},{ }^{232} \mathrm{Th}$, and ${ }^{40} \mathrm{~K}$ radioisotopes in two types of samples (soil, sand) from Tiba area in Luxor governorate. Results show the average activity concentrations of ${ }^{226} \mathrm{Ra},{ }^{232} \mathrm{Th}$, and ${ }^{40} \mathrm{~K}$ are $24.4 \pm 1.4 \mathrm{~Bq} \cdot \mathrm{kg}^{-1}, 23.3 \pm 1.1$ $\mathrm{Bq} \cdot \mathrm{kg}^{-1}$ and $302.2 \pm 6 \mathrm{~Bq} \cdot \mathrm{kg}^{-1}$, respectively for soil and $18.52 \pm 0.8,14.06 \pm 0.5$ and $210.9 \pm 6$ for sand. The results indicate that soil generally has higher natural radioactivity than sand in the same region. These values fall in the lowest range of the world values 30.35 and $400 \mathrm{~Bq} \cdot \mathrm{kg}^{-1}$ for ${ }^{226} \mathrm{Ra},{ }^{232} \mathrm{Th}$, and ${ }^{40} \mathrm{~K}$ respectively [16]. The radium equivalent activity $\left(R_{\text {aeq }}\right)$, internal hazard indexes $\left(H_{\text {in }}\right)$, external hazard indexes $\left(H_{e x}\right)$, absorbed dose rate $(D)$ and representative level index (I), for all samples under studying (soil-sand) were 81.07, 0.28, 0.21, and 0.59 respectively for soil samples, $65.81,0.19,0.14$, and 0.40 for sand. The results indicate that the dose rates at $1 \mathrm{~m}$ above the ground from terrestrial sources in all samples under investigation were 37.98 and $25.85 \mathrm{nGy} \cdot \mathrm{h}^{-1}$ for soil and sand samples respectively. These values agree with the world average value reported by UNSCEAR [17]. These values present no hazards to human. The surface exhalation and mass exhalation rates for radon from these different samples were reflected by their radium contents. The result indicates that the exhalation rates are higher for soil samples from than sand samples. The overall average of mass exhalation rate for samples under investigation is $1.69 \pm 0.12 \mathrm{~Bq} \cdot \mathrm{kg}^{-1} \cdot \mathrm{h}^{-1}$ and the average value for surface exhalation rate for radon in different samples is $29.86 \pm$ $0.35 \mathrm{~Bq} \cdot \mathrm{m}^{-2} \cdot \mathrm{h}^{-1}$. 

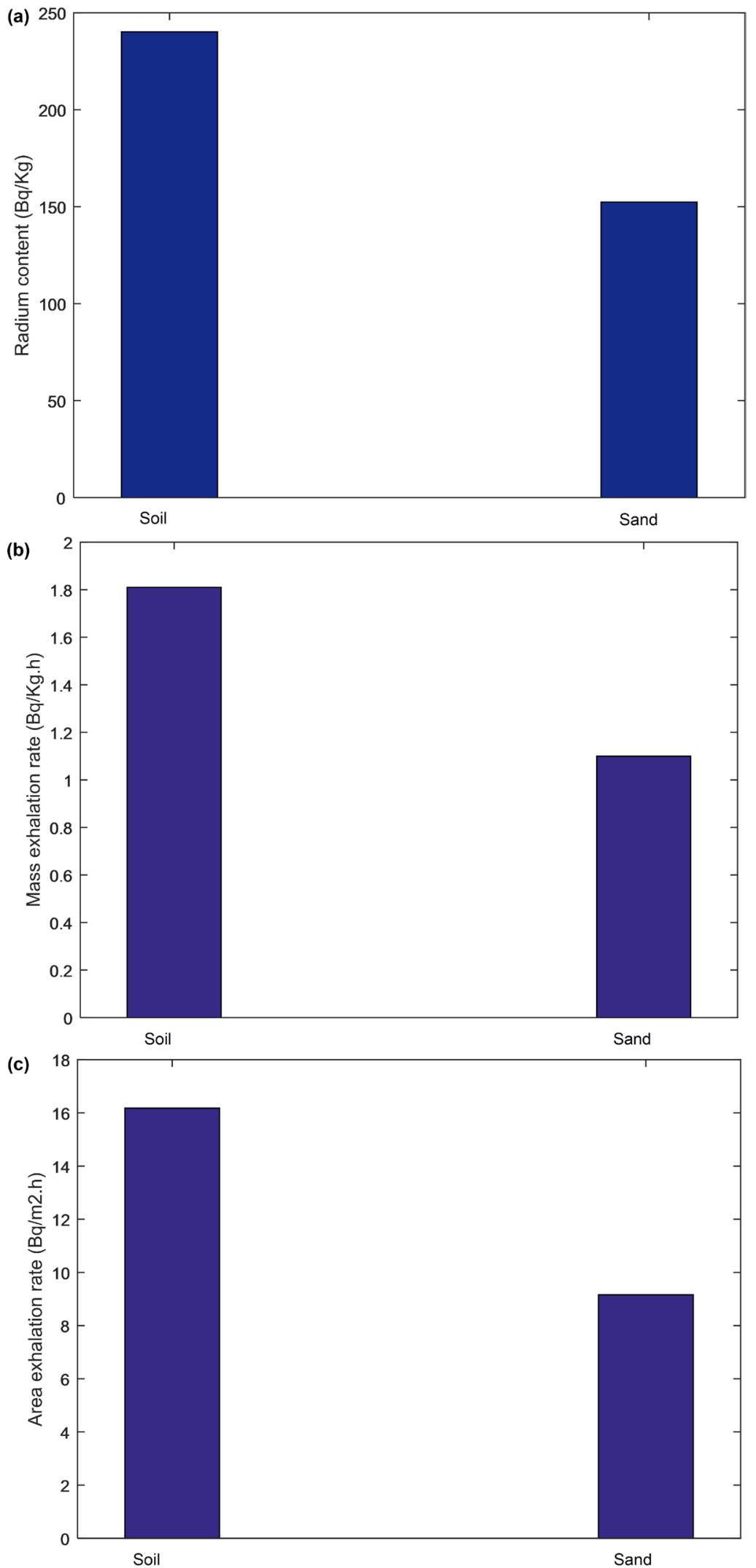

Figure 5. Average value for Radium content (a), mass exhalation rate (b), and area exhalation rate (c), for soil and sand samples. 


\section{Acknowledgements}

The author would like to thank the staff of High Institute of Engineering and Technology at Eltod for their support.

\section{Conflicts of Interest}

The authors declare no conflicts of interest regarding the publication of this paper.

\section{References}

[1] Abbady, A., El-Arabi, A.M., Abbady, A.G.E. and Taha, S. (2006) Gamma-Ray Measurements of Natural Radioactivity in Cultivated and Reclaimed Soil. Seventh Internal National Radiation Physics Conference, Beni Suef, 13-15 November 2006, 223-231.

[2] Ahmed, N.K. and El-Arabi, A.M. (2005) Natural Radioactivity in Farm Soil and Phosphate Fertilizer and Its Environmental Implications in Qena Governorate, Upper Egypt. Journal of Environmental Radioactivity, 84, 51-64.

https://doi.org/10.1016/j.jenvrad.2005.04.007

[3] Altschuler, Z.S. (1980) The Geochemistry of Trace Elements in Marine Phosphorites. 1. Charac Teristic Abundances and Enrichment. Society of Economic Paleontologists and Mineralogists Special Publication, Vol. 29, 19-30.

https://doi.org/10.2110/pec.80.29.0019

[4] Amrani, D. and Tahtat, M. (2001) Natural Radioactivity in Algerian Building Materials. The International Journal of Applied Radiation and Isotopes, 54, 687-689. https://doi.org/10.1016/S0969-8043(00)00304-3

[5] Hayumbu, P., Zaman, M.B., Lubaba, N.C.H., Munsanje, S.S. and Nuleya, D. (1995) Natural Radioactivity in Zambian Building Materials Collected from Lusaka. Journal of Radioanalytical and Nuclear Chemistry, 199, 229-238. https://doi.org/10.1007/BF02162371

[6] Mollah, A.S., Ahmed, G.U., Hussain, S.R. and Rahman, M.M. (1986) The Natural Radioactivity of Some Building Materials Used in Bangladesh. Health Physics, 50, 849-851.

[7] UNSCEAR (1993) Exposures from Natural Sources of Radiation. Report to the General Assembly, with Scientific Annexes, United Nations, New York.

[8] Radhakrishna, A.P., Somashekarappa, H.M., Narayana, Y. and Siddappa, K.A. (1993) New Natural Background Radiation Area on the Southwest Coast of India. Health Physics, 65, 390-395. https://doi.org/10.1097/00004032-199310000-00006

[9] P. Ziqiang, Y. Yang, G. Mingqiang, (1988) Natural Radiation and Radioactivity in China. Radiation Protection Dosimetry, 24, 29-38.

[10] Durrani, S.A. and Ilic, R. (1997) Radon Measurements by Etched Track Detectors: Applications in Radiation Protection, Earth Sciences and the Environment. World Sci. Publ. Co., Ltd., London. https://doi.org/10.1142/3106

[11] American Society for Testing and Materials (1986) Annual Book of ASTM Standards; 420. ASTM, Philadelphia, Report No. D, 109-113.

[12] Saad, A.F. (2008) Radium Activity and Radon Exhalation Rates from Phosphate Ores Using CR-39 On-Line with an Electronic Radon Gas Analyzer “Alpha Guard”. Radiation Measurements, 43, S463-S466.

https://doi.org/10.1016/j.radmeas.2008.04.052 
[13] Walley El-Dine, N., El-Sharsha, A., Ahmed, F. and Abdel-Haleem, A.S. (2001) Measurement of Radioactivity and Radon Exhalation Rate in Different Kinds of Marbles and Granites. Applied Radiation and Isotopes, 55, 853-860. https://doi.org/10.1016/S0969-8043(01)00107-5

[14] AquaKIT Manual (1999) Genitron Instruments GmbH, Germany 09/97.

[15] Mustonen, R. (1984) Natural Radioactivity in and Radon Exhalation from Finnish Building Materials. Health Physics, 46, 1195-1203. https://doi.org/10.1097/00004032-198406000-00003

[16] Barton, T.P. and Ziemer, P.L. (1986) The Effects of Plastic Size and Moisture Content on the Emanation of RN from Coal Ash. Health Physics, 50, 518-528. https://doi.org/10.1097/00004032-198605000-00001

[17] United Nations Scientific Committee on the Effects of Atomic Radiation (2000) Sources, Effects and Risk of Ionizing Radiation. United Nations, New York.

[18] Beretka, J. and Mathew, P.J. (1985) Natural Radioactivity of Australian Building Materials, Industrial Wastes and By-Products. Health Physics, 48, 87-95. https://doi.org/10.1097/00004032-198501000-00007

[19] NEA-OECD (1979) Nuclear Energy Agency-Organization for Economic Cooperation and Development. Exposure to Radiation from Natural Radioactivity in Building Materials. Report by NEA Group of Experts, OECD, Paris.

[20] Mantazul, I.C., Alam, M.N. and Hazari, S.K.S. (1999) Distribution of Radionuclides in the River Sediments and Coastal Soils of Chittagong, Bangladesh and Evaluation of the Radiation Hazard. Applied Radiation and Isotopes, 51, 747-755. https://doi.org/10.1016/S0969-8043(99)00098-6

[21] Krieger, R. (1981) Radioactivity of Construction Materials. Betonwerk Fertigteil Technology, 47, 468-473. https://doi.org/10.1016/S0160-3450(16)31258-2 